ARTICLE

\title{
'I Will Survive': Forty Years of Amber Films and the Evolution of Regional Film Policy
}

\author{
PAUL O'REILLY, Northumbria University
}

\begin{abstract}
This article explores the academically neglected yet frequently contentious issue of regional film policy in the UK, via an analysis of the financial history of a single cultural filmmaking collective, Amber Films. Based in the North East of England, since 1969 Amber has created a rich oeuvre informed by a strong social realist ethos, and underpinned by collaborative working practices which attempt to integrate local communities into all aspects of production and exhibition. Despite the remarkable achievements the group and its work have engendered, the narrative of economic survival that frames its history is as fascinating as any formulated during the development of its feature films. Due to the fluctuating dynamics of the company's relationships with a number of key film funding institutions and initiatives, the example of Amber provides an illuminating insight into the ambiguous paradigms that have dominated evolving cultural policies and procedures over the last four decades.
\end{abstract}

\section{KEYWORDS}

Amber Films; funding; Workshop Movement; Social Realism

\section{Introduction}

Debates surrounding the issue of funding for 'cultural' filmmaking in the United Kingdom have a long and contentious history. The vague incorporation of the term 'cultural' is as deliberate as it is necessary, for the application of nomenclature to filmmaking forms and practices within this very broad and terminologically-unsatisfying field of activity has been continually problematic. Regardless of the semantic debates however, this ragged conglomerate of filmmakers have historically relied upon financial resources generated by means other than the commercial value of their work. Thus the relationships developed between filmmakers, funding bodies and most importantly the state, have quite justifiably generated a great deal of debate within and around the industries of film and television. Despite the innumerable narratives that can be identified by focusing on any combination of these wildly oscillating relationships, only rarely has the issue gained sufficient attention in cultural studies, undoubtedly in part due to the 'overpowering sense of bureaucracy and officialdom’ they engender (McIntyre: In Moran 1996, p.217).

Whilst a reasonable amount of literature has been devoted to national film policy, the numerous attempts at developing regional industries have rarely generated enough cultural collateral to initiate a dialectic resulting in the materialisation of sustained financial support throughout the regions. There are of course notable exceptions to this economic rule of 
thumb, but for the most part filmmakers with little interest in fully integrating themselves into the 'mainstream' have found the matter of survival to be constantly perilous.

This simple economic situation has as many determinants as it does dependents and consequently a full dissection of the vicissitudes of regional film policy is far beyond the scope of this paper. Due to the constant precariousness of the cultural sector many filmmakers invariably cease production, adjust their practices to the most readily available financial stream, or wholly conform to commercial demands. However crude, this statement is by no means intended as an indictment of the professional decisions undertaken by filmmakers, but aims rather to highlight the rarefied examples of artistically consistent, productive survival, under frequently stringent conditions.

Newcastle's Amber Films is one example of such endurance. Due to the company's remarkable longevity, I propose that it serves as a perfect model for an analysis of a small but very significant aspect of film funding in the United Kingdom. From a socio-political perspective, debates around cultural funding in the regions contain particular pertinence in a climate where the more general issue of devolution has sustained contention throughout the last decade. Meanwhile the more immediately pressing concern over international economic deflation will undoubtedly have a profound impact on the funding of 'not for profit' cultural practice.

Further to this socio-political context, the rationale of using Amber as a vehicle by which to explore regional film policy can be equally justified within the context of film history. Without becoming embroiled in the terminological debates mentioned above, the origins of the collective neatly converge with those of a new model of 'counter-cinema' which emerged in the UK in the late Sixties. Whilst various historical narratives of what could broadly be defined as 'independent' cinema have been traced, there is clearly enough evidence to support the proposition that 1968 marks a definite rupture in any possible linearity. The BFI publication The New Social Function of Cinema puts the case forward:

The need for an alternative, counter, pedagogical, propagandist cinema practice in the face of a monolithic notion an audience was first indicated in this country in the Thirties.... From the late sixties, the British independent film movement has similarly developed, taking its impetus from the events of France in May 1968 and the upheaval of that period that fundamentally altered the relationship between state and public. (Stoneman and Thompson 1981, p.8)

This paper, therefore, will schematically trace the financial history of Amber Films through the foci of its encounters with a number of regional and national cultural initiatives, correlating with the formation of the collective in the late Sixties through to the present. My primary concern lies in the significance of these encounters to its survival. However, an analysis of the polysemous manner in which these convergences have manifested in Amber's filmmaking will be considered when relevant. Whilst the limitations of focusing on a single filmmaking collective are transparent, it is my aim to incorporate Amber's unique history into several wider spheres of interest. I do this in the hope of providing a framework for thinking about contemporary regional film culture and its rather awkward evolution.

After briefly addressing the terminology used to define Amber as a cultural filmmaking collective, I will introduce the central tenets of its history and filmmaking practice. The collective has received an amount of academic interest disproportionate to the significance of 
its work, and will thus no doubt be unfamiliar to a percentage of readers, hence the need for clarification.

\section{Defining the Collective}

I will refer to Amber primarily as a collective and where an alternative is necessary to avoid repetition, a group rather than as a workshop. This comes despite the fact that it was an integral part of the Film Workshop Movement, which comprised a plethora of groups with united passions for film, politics and a polemical critique of metropolitan, industrial hegemony and unbalanced forms of media representation. To quickly explain this need for definition: the terminology employed by the disparate array of small independent or oppositional filmmaking groups formed in the late 1960s was 'workshops' and 'integrated practice', terms which gained collateral as the need to clearly define their often diverse aims became a necessity. As Dickinson states, 'the groups fell broadly into two types, which later became known as 'access workshops' and 'collectives"' (1999, p.41). Access workshops were cultural centres with facilities that catered to the needs of an open membership. For example, the most famous of these, The London Film-Makers' Co-op, comprised of a fluctuating number of individual filmmakers who, despite certain shared objectives, often had variegated approaches to their art. Contradistinctively, 'collectives' tended to be small groups like Amber which worked together, occasionally providing facilities to other people for training or educational purposes, outside the realms of, or subservient, to their production work. Furthermore, whilst the emergence of the Film Workshop Movement in the wake of the ACTT Declaration lead to the term 'workshop' being widely adopted to describe highly contrasting activities across both forms of practice, it holds little semantic weight in a contemporary context, as the industrial structures and wider environment which were developed in support of the movement are now dormant or extinct.

It would be equally misleading to merely label Amber 'independent filmmakers', for the phrase has historical connotations which belie its working structures. From the late 1960s, the semantics of the word 'independent' (when used in relation to film culture) were hotly contested between those who wanted to claim it in the name of oppositional struggle, and those who applied it to small companies whose desire it was to operate within the confines of the (film) industry's mainstream. In the current climate the term is equally nebulous, and like Blanchard and Harvey I feel 'independent' 'denotes a convenient expression of the sectors vacillation' rather than a distinctive form of practice, much as the equally woolly and even less applicable tag 'alternative' (1983, p.241). Moreover, the term 'independent' suggests a position of decisive financial isolation from avenues of state support - something which Amber has actively opposed. For the same reason 'oppositional' (as coined by Dickinson) appears inappropriate for a collective which has continually sought to engage in dialogue with (without conforming to the practices of) terrestrial television broadcasters. At best, the vague principle of opposition - both politically and aesthetically - has on several occasions united those working outside or against 'the system' (that of capitalist hegemony) without any success in sustaining opposition to the degree that a radical alternative was plausible. Avant-Garde, on the other hand, implies a primary disposition to formal experimentation to which Amber does not prioritise, for it is quite clearly signified rather than signifier which takes precedent. 'Cultural', despite arguably being the most non-descript of all the above, most suitably describes Amber's work, being as it is specifically concerned with establishing film as an art and its role within local communities. Rather than becoming enmeshed in these 
descriptive debates any further, an introduction to the work of the collective summarises this reasoning more dynamically than any pre-existing definition.

\section{Amber Films: History and Practice}

Amber is a film and photography collective formed in 1968 out of a meeting of students at London's Regent Street Polytechnic. The group moved to Newcastle-upon-Tyne a year later, a decision undertaken primarily due to their desire to document the strong sense of identity and history embedded in the lives of the region's working-class communities. Amber has continually sought to celebrate its subjects and frequently, given its penchant for exploring marginalised lives, its filmic narratives have been infused with the stoic heroism of struggle and survival. Various inter-textual examples can be cited; the title of this paper, for example, refers to the Gloria Gaynor song of the same name, as sung by the long-suffering female protagonists at the end of Amber's feature Dream On (1992).

Despite forming in London, Amber made just two films in the city; the first of these, the controversially titled All You Need is Dynamite (1968) is the only Amber film to fully incorporate the radical modernist aesthetics and counter-cultural politics emerging (via the likes of Godard, Straub, Huillet, Brackage and Anger) from University campuses and film coops the world over. The move from metropolitan centre to the most northerly English province appears in diametric opposition to the widely-perceived magnetism of 'swinging' London upon the nation's politicized, cultured youth. However, several motivating factors can be cited for Amber's decision to relocate. Firstly the collective's members, though students in London, did not hail from the city and in the hope of re-connecting with their working-class roots opted to move to Newcastle, with its rich industrial, working class history.

At the time of Amber's relocation to the North East, the area was 'still relatively prosperous, a centre for ship-building, steel manufacturing and coal mining' (Honess Roe 2007, p.307). However, as has been well-documented, the following decades saw many areas within the region suffer from severe post-industrial decline, their economies ravaged by the effects of privatisation, an exponentially global market and a consequential increase in unemployment. As such many of the North East's working-class cornerstones disappeared and Amber's efforts to delineate the eroding traditions of work and leisure that underpinned them took on greater profundity. Such was the imminent demise of several of its industrial foci, that the prospect of Amber making a film on a subject usually rang a prophetic death-rattle within the given industry.

Early films tended to be short documentaries or the occasional animation piece, made via a mix of small grants from Northern Arts, Tyne and Wear County Council, educational institutions, private investors and various strategies of self-sustenance. Furthermore, these films were in fairly marked contrast to both Amber's initial appropriation of a modernist aesthetic in All You Need is Dynamite, and were instead rooted in a social-realist tradition which clearly acknowledges a debt to John Grierson's British Documentary Movement and its creative interpretation of reality. There is a poetic realism which infuses the images of Amber's early work, particularly Launch (1973) and Glassworks (1977), which transcend their relatively paltry financial investment via eyes keenly attuned to the transitory nuances of working life (Amber: In Fountain and McKeown 1983, p.16). Such attention to detail yielded from the relationships developed via the collective's integrative production strategies, which 
were dependent on the mutual trust developed with its subjects, and builds upon 'a tradition of enabling working-class self-expression that goes back to Bugle Blast, Penguin New Writing, and the work of Mass Observation during the Second World War' (Hunt 2007, para 4). An early instance of such appears in the short High Row (1974), in which the featured drift-mine workers, unhappy with their scripted lines, helped in the writing of a draft that conveyed their natural manner of conversing more accurately. According to founding member Murray Martin, and ironically considering the miners' involvement, Peter Sainsbury at the BFI Production Board criticised the dialogue for being 'totally romantic' (Martin: In Dickinson 1999, p.254). This issue of 'romanticising' working class lives is one which has consistently characterised criticism of their representational cine-lyricism.

Such methods of working have remained intact and Amber's most recent film drama Shooting Magpies (2005) - which looks at the effects of heroin on the communities of County Durham - features non-professional actors recreating their own lives. Such processes refer to models of anthropological docu-drama as fashioned by Flaherty, the British Documentary Movement, Mass Observation, Direct and Free-Cinema. As Grierson said of Flaherty:

Documentary must master its material on the spot, and come in intimacy to ordering it. Flaherty digs himself in for a year or two maybe. He lives with his people till the story is told out of himself. (Grierson, 1966, p.147)

Since Grierson's comment film theory has become increasingly sophisticated with discourses surrounding the realist dialectic being continually reworked. As such Amber has often been unfashionable in critical and (consequently) cultural quarters causing the collective difficulty in sustaining the required levels of funding. Single project funding - the economic model endemic of the cultural sector - does not tend to satisfy such unorthodox practice, and for Amber to survive revenue is paramount.

\section{Establishing Stability}

Upon its formation, Amber set up as a limited company, though this was re-structured as a partnership following a change of personnel in 1970 - a decision which coincided with their first wage structure. At this stage only one member of the collective (administrator Lorna Powell) was waged, whilst each of the other members balanced their filmmaking and photographic work with an eclectic range of part-time jobs (crewing for commercials and television, commissions) and business ventures (recycling driftwood, photographic framing and an educational slide library). Murray Martin employed equally innovative (if slightly less craftsman-like) endeavour in fund-raising through gambling. Martin had worked as a bookie's runner for his uncle as a child and 'in the early days he sometimes solved problems with a visit to the betting shop' (Rigby 2007, p.45). In keeping with the collective's egalitarian ethos, the money earned via these disparate activities funded their work and eventually established a minimal wage of $£ 5$ per week.

Amber's first application for funding via its respective Regional Arts Association Northern Arts, was turned down in 1968 and the group did not receive any public funding until 1972 when it obtained a fairly modest photography grant of $£ 150$. In 1975 Amber garnered its first stream of revenue funding from Northern Arts, receiving £25-30,000 per annum until 1996. Whilst the grants were relatively small the Regional Arts Associations (or Boards as of 1989) were an integral element in a devolution process whereby the Arts Council supported 
increased regional activity as part of its charter's obligations. Northern Arts funders were the BFI, the Arts Council of Great Britain, the Crafts Council and the Local and District Councils, and significantly Northern Arts was the first of the RAAs to recognise film as an art form when in 1966 it established a panel and budget to cater for the medium; its grant to Amber included a small wage.

Whilst Northern Arts funding provided a modicum of stability and freedom, it was not substantial enough to develop more than fairly modest projects. The dilemma of attracting further revenue was by no means exclusive to Amber or filmmakers of the 1970s, having blighted 'independent' filmmaking since the post-war period. Whilst the BFI Experimental Film Fund and subsequently the BFI Production Board had benefited apprentice filmmakers and avant-garde practitioners, it never really succeeded in establishing a stable 'independent' sector with a regional profile, despite its partial funding of the RAAs. British 'independent' film has historically been defined 'by its funding agencies, whose policies determine what films can be made and how they are likely to be distributed', and in the 1970s this equated to a modest amount of films with haphazard distribution (Aspinall 1984, p.73). Prior to the 1980 s the BFI, either directly via its own financial rhetoric or indirectly via its RAA payments, was largely responsible for the funding of the gamut of experimental, cultural and avant-garde work, regardless of the associated nomenclature. These forms of short-term funding which dominated the sector throughout the 1970s left filmmaking groups in a constantly precarious position, frequently consumed by the bureaucratic procedures involved in applying to sources with very different and frequently-changing criteria. Survival in this climate required a great deal of acumen, a majority of which in Amber's case came outside the conventional parameters of film production.

Along with its egalitarian syndicalism, a key component of Amber's operation in the 1970s was its astute attitude to property investment and development. Buying and trading has always been preferred over hire or rental, and the security and flexibility that this allows has been beneficial. After an initial period renting, the collective was able to accumulate enough money via a mix of loans and outside work to purchase its Side premises for £12,000 in 1975. The building straddles both sides of a narrow alleyway and houses Amber's photographic gallery, 53 seat cinema, café, darkroom, workshops and an office space. In hindsight this decision was crucial to Amber's survival, and relieved the added pressure of rental overheads. Furthermore, the image of Newcastle's Quayside has changed dramatically over the last decade. From what was in danger of becoming a dilapidated industrial wasteland has emerged a vibrant (depending on your cultural perspective) area of leisure with increased passing trade.

It was the scale of these brave decisions in the mid 1970s that helped attract the revenue funding from Northern Arts, enabling the consequent expansion of Amber's operation. However, what the collective and its contemporaries craved was a union-approved constitution within which to operate, regular (and greater) revenue funding and a means of distributing and exhibiting its work on a wider basis. Crucial to the evolution of this process was the formation of the Independent Filmmakers' Association in 1974, a short-lived but vitally important grouping of vanguard filmworkers, sustained via a combination of grants and subscriptions and committed to developing an alternative media. The IFA (as of 1983 the IFVA and 1986 the IFVPA) spearheaded a number of campaigns (with regional concerns high on the agenda) and was a key player in the debates around a fourth terrestrial television channel, the birth of which came in 1982. Rather than producing its own material, the channel would operate as a publisher-broadcaster. Thus, via its original remit to innovate and 
experiment in the form and content of programmes', it opened up an unheralded exhibition space for 'independent' producers (Great Britain: Independent Broadcasting Authority 1981, p.14). Along with the BFI (which initially funded two production units via its annual government grant from the Department of Education and Science), Channel 4 offered the majority of the funding for eight filmmaking groups enfranchised under the ACTT Workshop Declaration.

\section{Consolidation and Unionisation}

The Workshop Declaration was a ground-breaking agreement promulgated by the ACTT in 1982 (revised in 1984), in consultation with the English Regional Arts Associations, the Welsh Arts Council, Channel Four and the BFI, recognising the alternative practices of the proto-'workshops' and constituting them to encourage a cultural, social and political contribution to society. The declaration was a radical step for a traditionally closed-shop union, and established working practices in the non-profit, cultural sector. Groups of four or more full-time members whose funding derived from public sources and who engaged in non-commercial work on a not-for-profit basis were enfranchised by the ACTT and given a condition to grant aid for a period of 1, 2 or 3 years, freeing them from 'the tyranny of continually searching for insecure short time funding from arts organisations' (Root 1984, p.4). As Amber worked tirelessly in helping shape the agreement, it is hardly surprising that it benefited from its terms, though it was not alone in doing so. Of immediate significance was that the ACTT placed the cultural and political ideologies of its new membership before wage concerns in allowing the groups to operate on an egalitarian minimum wage structure of $£ 8000$ per annum. The recognition of cross-grade practice also allowed filmworkers to gain experience in a range of roles whilst, in probably the most rewarding clause for Amber, the agreement stipulated that the group and not the commissioner would own sole copyright to the work.

Dialogue between the groups and the channel was refreshingly open with a regular exchange of ideas; perhaps unsurprisingly given the number of IFA apparatchiks that gravitated toward the new broadcaster, spearheaded by commissioning editor for Independent Film and Video, Alan Fountain. Amber's Channel Four revenue grew from $£ 48,000$ to $£ 90,000$ a year between 1982 and 1991, with a majority of commissions coming from Fountain's department and screened via the innovatively programmed Eleventh Hour and People to People strands.

The most visible manifestation of this liberating revenue stream came via Amber's first foray into feature filmmaking with Seacoal (1984). The relationships developed with its seacoaling subjects spurred another of the collective's forays into enterprise as Amber (explicitly Murray Martin) became drawn into the world of harness racing (later the subject of their film Eden Valley, 1994). Not only did Martin buy and race a horse on the circuit, he also became fully ingrained into the harness racing community, developing personal and professional relationships and helping in the setting up of the UK Standard-bred Racing Association. With Amber's policy of pooling income, the money earned - as with that emanating from their other business ventures - was fed back into the funding of Amber's work.

Despite its great significance, the purchase of the Side was not the only acquisition in the collective's portfolio. As a further workshop space, Amber bought a disused North Shields chapel and also a pub, The New Clarendon, which served as a meeting place, social centre and frequent film location. During its work in North Shields, the pub provided Amber with a 
base which allowed the collective to 'integrate into people's everyday lives, against a real backdrop of evolving social and industrial history' (Amber: In Whale 1986, p.97). Perhaps the most eccentric of these purchases came in 1989, when Amber bought the Sally: an anchor seine fishing boat acquired in Denmark. The boat would serve as primary location for its subsequent feature on the fishing industry In Fading Light (1989), and allowed Amber to send its cast out to sea for two months to train as fishermen before starting filming.

At a regional level, Amber, along with the other North-East workshops and in partnership with Tyne and Wear County Council, helped set up the North East Media Development Council in 1982 (undoubtedly influenced by the GLC's cultural industries policies). The council subsumed three initiatives within its remit: a Media Development Agency, which sought to encourage new initiatives in programme making and media culture; a Media Training Centre offering a two year course to young people; and PRIMO, a marketing and distribution arm geared towards developing the sales of programmes in broadcast and nonbroadcast markets. The tripartite aim was to promote a regional media organised on the workshop model, and to improve the financial performance of the independent audiovisual sector by tapping into local, national and European streams of funding. However, the Development Council ran into financial difficulties as local funding dried up in the mid 1990s and the scheme quickly collapsed. The development of such training schemes throughout the regions often took over from production as a priority, as serious public money could be obtained from central and local government, which rather than supporting an 'independent' sector could 'be seen as little more than rather crude attempts to massage unemployment figures' (McIntyre 1996, p.228).

Whilst NEMDC ultimately failed in maximising the regional networking skills of North East filmworkers, The Miners' Campaign Tapes project (1984) was hugely impressive on a regional and national scale. The project brought together a network of cultural practitioners and social activists in the production of six VHS tapes (packaged in pairs) which attempted not just to re-balance inaccurate media reportage of the event, but also to actively 'participate in and promote the strike' acting as a form of 'cultural praxis' (James 1997, p.251). Amber's Graeme Rigby has subsequently cited the work on The Miners' Campaign Tapes as marking a sea-change in attitudes towards funding for cultural work and its legitimate function within arts and media, stating that, 'after the miners' strike the funding bodies stepped back' (Rigby: In Newsinger, J. 2007).

Whilst the ACTT Workshop Declaration (like Channel Four) was conceived during a period of liberal debate under a Labour government, it only became reality after Thatcher had replaced Callaghan in power, ensuing a period of Conservative dominance the hallmarks of which (deregulating and extending the market, breaking up the unions, deflationary fiscal policies, a reliance on independent experts and private think-tanks and cuts in cultural funding) brought about inevitable complications for the sector. Whilst the ACTT had lobbied for the economy to support the film industry (radically in 1973 when they proposed the industry's nationalisation), it was now very much a case of what the industry - and culture in general - could do to support the economy. The workshops' not-for-profit status, collective, anti-hegemonic structures and didactic modes of agit-prop criticism clearly threatened the dominant capitalist ideologies of both Thatcherism and the commercial industries of film and television which they had partially infiltrated.

Despite the ineluctable difficulties which began to entrench the sector towards the end of the decade, the mid-eighties marked the apotheosis for workshop filmmaking in both the 
development of its infrastructure and the work carried out. Along with the miners' strike, mass-rioting (St Paul's, Brixton, Toxteth, Handsworth, Broadwater Farm), the Falklands war and high unemployment levels generated a violent socio-political context against which a politically motivated cultural sector became a vital outlet for the disenfranchised.

The controversial abolition of the County Councils by the Conservative Government in 1986 further limited the regional funding available, with money previously distributed by Tyne and Wear (who supported Amber's film Bowes Line, 1975 as well as the NEMDC development) instead held by local authorities who placed film, particularly grant-aided work such as Amber's, very low on its list of priorities. It would be unfair to merely consider the demoralising effects this act had on the cultural landscape of the North East, as each of the six concerned regions along with the capital (via the demise of the GLC) found applications for local funding disappearing into an ambiguous mire of palocracy.

It is arguable that Amber expanded too rapidly in the 1980s, with workshop funding at its height, leaving it exposed to funding cuts. A smaller group, whilst unable to undertake as much work, is undoubtedly more secure in its ability to survive any flux in the constantly fragile cultural climate. The change that ultimately occurred as a result of Channel Four's restructuring of its workshop funding policy in the late 1980s helped dismantle the movement as quickly and dramatically as it had enabled its very being. It would be naïve to identify the channel as being solely responsible for this downfall, as its changing rhetoric reflected both problematics within the ACTT Declaration and the wider political climate.

Whilst Channel Four provided a new audience for the sector, tensions arose about how workshop productions and the modes of address required in its programming would match up with the channel's initial remit. Work such as Amber's, for example, was (and is) clearly predicated upon the generation of dialogue between filmmaker, subject, text and audience; something conventional broadcasting paradigms do not aid in formulating. Whilst having the revenue funding required to perpetuate the production process was of enormous benefit to the filmmaker initially, if the text did not engage with its audience (Channel Four's rather than that of the small cinema/ venue screening otherwise most common to cultural material), then neither filmmaker nor broadcaster could be truly satisfied and this issue quickly became critically contentious. Within one year many of these contentions were manifested in the pages of Screen (see Screen 25, 2: pp.4-25), part of a wider feeling of disenchantment with blame directed at several parties: Channel Four commissioning editors, IFVA filmmakers and critics, Thatcherism and marketisation. Some groups felt that the declaration was unrepresentative to begin with, serving more as an agreement for grant-aided groups than all workshops, being that it was difficult to qualify for enfranchisement unless you had already secured revenue. This was certainly a source of tension in the North East with six workshops operating at some point during the decade (A19, North East Films, Siren, Swingbridge, and Trade Films along with Amber), though only Amber and Trade were fully franchised throughout the 1980s. More topical still was the controversial (and age-old) issue regarding the movement's dependency on state funding and the feeling in some quarters that this ultimately elided the objectives of recalcitrant, oppositional practice.

Splinter groups who felt their ideologies could be better represented outside the IFVPA, such as NOW - the National Organisation of Workshops - were set up (with the active involvement of Amber) to serve franchised groups. Some felt that the IFVPA was an organisation which served as a centre for introduction and advice for inexperienced filmworkers, but that upon gaining union membership its usefulness became obsolete; the 
possibilities within the union environment were conceived as greater. However, the ACTT did not serve as a conduit between regional groups because not all practitioners in the field were ACTT members. The IFVPA, on the other hand, did function as a communal body; though if members left upon joining ACTT, the potentialities of regional networking within the sector were stunted. This should not paint the IFVPA as a utopian alliance however, as even during the height of its membership various factions understandably emerged with their own agendas. As these factions gradually gravitated elsewhere, the IFVPA's position was weakened, and by the time of its dissolution it was unable to serve as the platform for debate it once did. The IFVPA eventually folded in 1990 - just 8 weeks after the BFI ceased its subsidy. The radical intellectualism of the 1970 s and early eighties gave way to an increasing populism as the BFI distanced itself from any agit-prop concept of 'political' cinema.

Without a superstructural framework within which to convene, it became increasingly difficult for those remaining to pursue their mainstream opposition in any sustained or perceptible way, and perhaps unsurprisingly NOW lasted little longer. Networking became more problematic and as such fresh approaches to accessing funding, new avenues of distribution and exhibition and alternative practices were required in order to survive.

\section{Beyond the Workshop Movement}

The early 1990s was a particularly difficult time for cultural filmmakers in the UK. Funding had all but dried up, the surrounding infrastructure had collapsed and the Conservative government entered its third term, enforcing changes in cultural and educational policies pernicious to practitioners. Cuts in funding made the most visible and immediate impact, however the advent of video tape had made schools, colleges and libraries significant outlets for groups to show their films, though as budgets were decreased film hire was no longer considered imperative. In colleges, the courses that would most readily incorporate cultural film (the 'recreational' ones) were often removed from the curriculum altogether. Furthermore, unemployment, anti-union legislation and declining public services made it hard for many workshop filmmakers to make a living from a mixture of part-time jobs, teaching and benefits as they had done in the 1970s, and in this climate the ACTT began losing its ability to enforce legislation. Funding bodies found that the scope of their work was narrowed, as administrators within the cultural sector became increasingly governed by concepts of affectivity, business studies rhetoric and a language of economic development. Consultants instead of researchers were hired, and were highly critical of business practices that differed from British standards, especially collectivist, non-hierarchical ones. Community engagement was not a priority for the emerging film funding models and it was hard to maintain the level and range of work of the 1980s.

This climate of commerce also saw Channel Four become responsible (as of 1993) for the selling of its own advertising. From its inception, Channel Four's programme-making was financed by indirect advertising in the form of a subscription from the ITV companies (in return for which they sold and collected income from Channel Four's advertising). Subsequently the channel was in the hitherto unfamiliar position of competing for advertising revenue and ratings. Naturally, the plurality of programming and level of risk-taking reduced to fulfil this requirement. Whilst the channel's revenue funding policy for the 'sector' had already been redrafted (or rather removed) as of 1989, the likelihood of even a single commission now appeared remote in light of these new demands. 
Amber scaled back its operation, with the cinema closing and gallery activity severely reduced. In total Amber received $£ 1.2$ million from Channel Four, making four features and two short dramas - in total 500 minutes of broadcast work. With its previous majority funding body redrafting its cultural remit, the collective looked elsewhere for support, finding it in 1995 in the somewhat unexpected domain of the BBC. This money, though projectbased development aid rather than revenue, assisted in the making of their features The Scar (1997) and Like Father (2001) and allowed Amber to retain ownership in a way full production funding would not. When Amber has been offered larger sums, it has often come with such a compromise - usually the installation of a professional writer - something that clearly conflicts with its practices, which remain in line with the archaic ACTT Workshop Declaration.

The mid nineties also saw the establishment of Channel Five and various cable and satellite channels, along with the growth of new media, all offering potentially larger outlets for regionally-based producers. However, Amber struggled to infiltrate these burgeoning markets and without the BBC's impetus it is difficult to envisage how it could have remained productive, as in 1996 its remaining stream of revenue from Northern Arts was terminated under that organisation's new funding policies, pre-empting the re-structuring of the entire cultural sector that occurred over the following years.

The UK Film Council was set up in April 2000 by the Department for Media, Culture and Sport, with all film money governed by the Lottery Act of 1998. Northern Arts was wound up in 2002 under the restructuring of the Regional Arts Boards (which were subsumed into Arts Council England), and responsibility for regional film funding was subsequently taken over by Northern Film and Media (one of nine regional 'mini film councils'). An increase in bureaucracy and hugely inflated running costs followed (from two film officers at Northern Arts to a current staffing of 19 at NFM), and this led to a great deal of dissatisfaction over the somewhat inexplicable proliferation of 'middle-men'. These bureaucratic structures and ideologies based upon target-setting clearly reflect both the current and previous governments' cultural and economic politics.

Amber has found the UK Film Council (via NFM) fairly unsupportive to its plight, and despite its rhetorical commitment to cultural film in the UK, the Council's overreaching objective of developing a 'sustainable UK film industry' does appear to be plagued by discrepancies between rhetoric and practice (UK Film Council 2002, p.5). As Newsinger states, 'the language with which the Film Council talks about culture seems to be in line with other cultural policy which is around ideas of 'diversity' and 'social inclusion' whereas in the 1970s and the 1980s there was much more explicitly politicised ideas behind public funding for film' (Newsinger 2007). Despite the underlying political current in Amber's work, it is rarely radical in a fundamentalist or revolutionary sense but rather steeped in a more general tradition of socialist egalitarianism and defined by community integration. So whilst the Council has arguably distanced itself from such 'explicitly politicised ideas', its rhetorical doctrines of 'diversity' and 'social inclusion' would appear more finely attuned to Amber's project than ever before. The practicalities of regional funding remain complex however, and despite Amber's continued methodological strategies of 'social inclusion', it has only been able to get small amounts of development money from NFM (usually between $£ 5000$ and $£ 10,000)$.

Fortunately for the collective, a new stream of funding materialised via the philanthropy of independent charity in 2003, when it secured the desired revenue via a five year, $£ 100,000$ 
per annum grant from the Northern Rock Foundation. The foundation's policy of ensuring the 'continued cultural regeneration of the North East' would appear to converge neatly with the work of Amber (Finn 2004, para 3). Sadly even this upturn in fortune has been fraught with complexity, as Northern Rock suffered hugely publicised financial difficulties earlier this year and the stability of the foundation was immediately endangered. The Government has asked the bank's board to identify a viable long-term future for the foundation and its status remains temporarily stable with guaranteed support until 2010. Whether Amber's revenue will continue past the agreed five years (which is due to expire in 2008) remains to be seen.

Whilst economic stability remains as precarious as ever, Amber has continued to subtly adapt its filmmaking to its financial situation. The most visible consequence of this evolution is evident in the collective's recent appropriation of digital technologies in Shooting Magpies. The film was Amber's first feature shot fully on digital video; a switch that has helped in reducing production costs and maintained its unique methodologies in several ways. Firstly the physical attributes of digital video cameras make it possible for a single person to film on the fly, the considerably smaller DV equipment allowing for 'reduced set-up times, almost unlimited and unobtrusive access to people's homes, and a greater mobility in general' (Hochscherf and Leggott 2007, p.112). Furthermore, transporting footage onto computer and the greater flexibility afforded by the resulting editing process allows several cuts to be produced more readily, whilst the group is not constrained in doing so via the confines of a traditional editing suite.

As technology becomes more affordable and widely accessible, the possibility of producing technically proficient work of broadcast quality on a small budget is increased, though that is no guarantee of artistic merit. Indeed the proliferation of audio-visual material sent forth into the public domain via multifarious media receptacles has flooded the field of activity as successfully as it has liberated a number of low-budget practitioners. Siphoning the quality from the quantity is frequently due to the fortuity of a chance encounter rather than the result of surveying a highly structured and innovatively exhibited collection of work and whilst new technologies (explicitly the internet) provide a ready-made environment for the distribution of 'niche' product, its success in identifying and addressing its audience requires a great deal of creative foresight. The paradox herein is that as the production costs for cultural film decrease (disregarding inflation), the less likely large amounts of revenue funding will be made available from any source. If a shoe-string budget is sufficient then as likely as not, that is all that will invested by funding bodies. The technological strategies incorporated by Amber therefore, need the utmost deliberation and will almost certainly define its future survival.

Whilst a digital future is pondered, retaining and engaging established audiences is vital and the collective continues to tour its films around the working-class communities of the North East, with screenings in a variety of unorthodox venues. An even broader audience should be reached in December 2008 when Channel Four subsidiary More 4 screens a new Amber documentary, The Pursuit of Happiness (2008), a joint narrative about a County Durham family and recently-deceased Amber founder Murray Martin. The structural make-up of the collective and the numbers employed within it have fluctuated (only one of Amber's founding members - Sirkka-Liisa Konttinen - remains within its seven full-time personnel), but as the collective states in its online biography: 'Obstinacy, a largely self-sufficient craft base, an integrated approach to production, publication and distribution, the readiness to make strategic investments and, increasingly, ownership of its back catalogue' have contributed to Amber's survival (Amber 2006, para 2). 


\section{Conclusion}

At present, cultural filmmaking falls into a miasmic paradox between UK Film Council rhetoric and practice; an ill-defined sub-sector within an industry of capital assessment and expenditure which has become increasingly blighted by the dogmatism of enforced bureaucracy and target meeting. Amber has been critical of the current state of film funding, arguing for a truly regional form of investment which is accountable to the public, developed under guidelines of trust and respect for filmmakers and nurturing in its attitude to local talent via equilateral regional investment. Such investment could help, as Amber's (now former member) Pat McCarthy states:

...to address some of the problems of disengagement in public life, stimulate greater involvement in politics, encourage involvement in community activity and help to enhance cohesion in our multi-cultural society (McCarthy, n.d., para 9).

Recent history suggests that such optimism will be dashed. The almost comical convergences between centralisation and devolution that have resulted from the attempts by several governments over the past two decades to re-structure arts funding have engendered an increasingly confusing state of affairs. The perils of bureaucracy leave practitioners frustrated and academics perplexed at all that is 'delightfully loopy about the systems and structures of funding and support for arts in the United Kingdom' (McIntyre 1996, p.218). This peculiar narrative of cultural economics is punctuated with 'contrary principles' that have often vied with one another, 'frequently resulting in contradictory and sometimes thoroughly incoherent compromise solutions' (McGuigan 1996, p.65). Ultimately more time and money have been spent in the process of distributing funding than on production. For an overhaul of these policies it will take the collective endeavour of all those with an interest in the production and reading of cultural film; something which at present appears unlikely given the fragmentation of activity.

What was once a vast network of film workshops, structured around the nucleus of the IFA, ACTT, C4, the BFI and the Regional Arts Associations/Boards, is now an ever-decreasing and industrially ambiguous number of surviving groups dependent on correlatively diminishing sources of funding. Many of those that briefly flourished under the ACTT Workshop Declaration have since disbanded, conformed to the practices of commercial production or re-structured their activities to concentrate on alternative, financially plausible forms of filmmaking; namely educational, instructional or community film.

Amber and its workshop contemporaries must shoulder at least some of the responsibility for the dissolution of the sector, as the fracturing of interests that emerged following ACTT enfranchisement and the subsequent splits between factions (IFA and ACTT, IFA and NOW, franchised and non-franchised groups) undoubtedly weakened their argument(s) and negated the dialectic they had promulgated through collective activism. However, these ambitions collided with the vestiges of The (socialist) Labour Party, and the generation of a number of cultural and commercial opportunities that briefly allowed their work a wider audience. It is no coincidence that as Thatcher's monetarist policies became the economic standard, the major funding bodies (several of which were state funded) would eventually have to become accountable and adapt to their rhetoric of commerce. Thatcherism undoubtedly marks a rupture in British political history and the numerous attempts at restructuring the cultural 
industry that have followed in its wake have sadly regurgitated many of that project's ideologies.

Amber's working methods are anathema to these short-term cultural economics. Its filmmaking practices are defined by egalitarianism and a democratic approach to creativity which is diametrically opposed to both romantic notions of art and also commercial filmmaking structures, defined as they are by hierarchy and clearly demarcated craft-roles. It is unsurprising, therefore, that Amber has encountered critical and financial obstacles throughout its existence, and whilst its work is too frequently overlooked, Amber constitutes 'possibly the most successful 'studio' - in terms of sheer longevity - in British film history' (Wayne 2001, p.48). In the face of such cultural hostility, coupled with their unwavering singularity of vision, survival is indeed a remarkable achievement.

\section{References}

Amber (2006) About Us: Amber History - 1968 to 1974 [online] Newcastle-upon Tyne: Amber. Available From: www.amber-online.com/history chapters/1968-1974 [accessed 28 August 2008]

Aspinall, A. (1984) The Space for Innovation and Experiment. Screen 25(6) 73-87

Blanchard, S. and Harvey, S. (1983) 'The Post-War Independent Cinema - Structures and Organisations' in Curran, J. and Porter, V. (eds.) British Cinema History London: Weidenfeld and Nicholson 227-241

Dickinson, M. (ed.) (1999) Rogue Reels: Oppositional Film in Britain, 1945-90

London: BFI Publishing

Ellis, J. (1984) Channel 4 - One Year on Screen 25(2) 4-25

Finn, L. (2004) Archive News: February 2004 [online] Newcastle-upon Tyne: Northern Rock Foundation. Available From: www.nrfoundation.org.uk/news/news Feb04a.html [accessed 28 August 2008]

Fountain, A and McKeown, G. (1983) New Independents on Four London: Channel Four Television

Great Britain. The Independent Broadcasting Authority (1981) Broadcasting Act 1981 London: HMSO

Grierson, J. (1966) Grierson on Documentary: Edited and Complied by Forsyth Hardy, Second edition London: Faber

Hochscherf, T. and Leggott, J. (2007) From Launch to Shooting Magpies: Locating the Amber Film Collective in Fawcett, H. (ed.) Made in Newcastle: Visual Culture Newcastleupon Tyne: Northumbria University Press 101-115

Honess Roe, A. (2007) 'Spatial Contestation and Loss of Place in Amber's Byker' Journal of British Cinema and Television 4(2) 307-321 
Hunt, M. (2007) Amber Collective [online] London, BFI Screen Online. Available From: www.screenonline.org.uk/people/id/502352/ [accessed 28 August 2008]

James, D.E. (1997) Power Misses: Essays Across Unpopular Culture London: Verso

McCarthy, P.A. (n.d.) Failure of Vision [online] Newcastle-upon Tyne, Neil Young's Film Lounge. Available From: http://jigsawlounge.co.uk/film/amber.html [accessed 28 August 2008]

McIntyre, S. (1996) 'Art and Industry: Regional Film and Video Policy in the UK' in Moran, A. (ed.) Film Policy: International, National and Regional Perspectives London: Routledge 215-223

Newsinger, J. (2007) Together We Stand [online] London: Vertigo. Available From: www.vertigomagazine.co.uk/showarticle.php?sel=bac\&siz $=0 \& i d=838$ [accessed 28 August 2008]

Rigby, G. (2007, September 8) Obituary: Murray Martin, Filmmaker and Founder Member of the Progressive Amber Collective. The Guardian, p. 45.

Root, R. (1984) New Waves London: Channel Four Television

Stoneman, R. and Thompson, H. (eds.) (1981) The New Social Function of Cinema Catalogue of British Film Institute Productions 79/80 London: British Film Institute

U.K. Film Council (2002) Towards a Sustainable UK Film Industry London: UK Film Council

Whale, M. (ed.) (1986) The Work of Channel Four's Independent Film and Video Department; Eleventh Hour; People to People; Workshops. London: Channel Four Television 